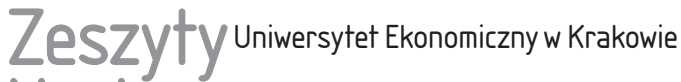 Naukowe
}

\section{Elastyczność rynku pracy w Polsce w świetle teorii optymalnych obszarów walutowych}

\section{Streszczenie}

Elastyczność rynku pracy jest rozumiana jako zdolność rynku pracy do płynnego dostosowywania się do zmiennych warunków gospodarczych. Sprawne funkcjonowanie rynku pracy i jego elastyczność zależą od zdolności do szybkiego reagowania popytu na pracę oraz podaży pracy na zmiany zachodzące w gospodarce. W kontekście teorii optymalnych obszarów walutowych rola elastyczności rynku pracy jest jeszcze większa, ma ona stanowić bowiem alternatywę wobec elastyczności kursów walutowych w wypadku amortyzowania szoków w unii walutowej. Celem artykułu jest przeprowadzenie analizy aktualnego poziomu elastyczności rynku pracy w Polsce, w szczególności w kontekście kryteriów teorii optymalnych obszarów walutowych. Najważniejszym wnioskiem płynącym z przeprowadzonych badań jest stwierdzenie, że poziom elastyczności rynku pracy w Polsce nie jest dostateczny. W związku z tym elastyczność rynku pracy w Polsce nie może stanowić alternatywy dla elastyczności kursu walutowego w dostosowaniach makroekonomicznych.

Słowa kluczowe: elastyczność rynku pracy, teoria optymalnych obszarów walutowych, strefa euro, unia walutowa.

Klasyfikacja JEL: E24, F15, F16, F22, J01, J2, J61.

Marcin Kawalec, Uniwersytet Ekonomiczny w Krakowie, Studia Doktoranckie, ul. Rakowicka 27, 31-510 Kraków, e-mail: marcin.kawalec.uek@gmail.com 


\section{Wprowadzenie}

Elastyczność rynku pracy w ogólnym ujęciu jest rozumiana jako zdolność rynku pracy do płynnego dostosowywania się do zmieniających się warunków. Ważną rolę odgrywają w tym zarówno zmiany w poziomie płac i wydajności pracy, czyli strona popytowa rynku pracy, jak i elastyczność wynagrodzeń, czyli strona podażowa. Sprawne funkcjonowanie rynku pracy i jego elastyczność uzależnione są zatem od zdolności rynku do szybkiego reagowania w zakresie popytu na pracę oraz podaży pracy na zachodzące w gospodarce zmiany (Kryńska 2001, Ostoj 2006).

W kontekście teorii optymalnych obszarów walutowych rola elastyczności rynku pracy jest jeszcze istotniejsza. Zgodnie z tą teorią elastyczność rynków pracy ma być substytutem elastyczności kursów walutowych w wypadku amortyzowania szoków w unii walutowej (Borowiec 2011, s. 288). Zdaniem twórcy tej teorii R.A. Mundella (1961) w każdym obszarze walutowym rynek pracy powinien być w wysokim stopniu elastyczny, m.in. w zakresie mobilności czynników produkcji, ponieważ w takich warunkach nie ma potrzeby dostosowywania kursu walutowego, a co za tym idzie, możliwe jest jego usztywnienie, niezbędne do przyjęcia wspólnej waluty.

Wstępna analiza wyników dotychczas przeprowadzonych badań nad elastycznością polskiego rynku pracy dostarcza umiarkowanie optymistycznych wniosków. M. Jadamus-Hacura i K. Melich-Iwanek (2015, s. 46) stwierdziły, że w badanym okresie (w latach 2002-2012) Polska należała do grupy państw o średnio elastycznym rynku pracy. $Z$ badań tych wynika również, że otwartość polskiej gospodarki wzrastała w badanym okresie, o czym świadczy coraz wyższa pozycja w rankingu zaproponowanym przez autorki. Badania te pozwoliły na sformułowanie wniosków odpowiadających tym, które zaprezentowała wcześniej A. Ertman (2011, s. 59-62) - są ich uzupełnieniem.

Podobnych wniosków dostarcza najnowszy raport przygotowany przez Forum Obywatelskiego Rozwoju Indeks elastyczności zatrudnienia 2018. Wynika z niego, że Polska zajmuje dopiero 30 miejsce wśród 41 badanych krajów UE i OECD. Warto jednak zauważyć, że badanie to dotyczyło elastyczności umów o pracę, a więc wybranego aspektu elastyczności rynku pracy (Trzeciakowski 2017).

Celem artykułu jest analiza aktualnego poziomu elastyczności rynku pracy w Polsce, w szczególności w kontekście kryteriów teorii optymalnych obszarów walutowych. Pozwoli to na ocenienie, czy warunek optymalności jest spełniony, a więc czy elastyczny rynek pracy może skutecznie zastąpić elastyczność kursu walutowego w dostosowaniach makroekonomicznych, a tym samym, czy usztywnienie kursu walutowego w wypadku Polski jest dla niej wskazane. 
W artykule zaprezentowano najważniejsze zagadnienia dotyczące elastyczności rynku pracy oraz przedstawiono jego rolę w stabilizowaniu gospodarki w kontekście teorii optymalnych obszarów walutowych. Poddano analizie ogólnodostępne dane statystyczne Eurostatu dotyczące wybranych aspektów rynku pracy w Polsce i odniesiono je do sytuacji w UE i strefie euro.

\section{Elastyczność rynku pracy}

Elastyczność rynku pracy jest jednym z istotnych zagadnień zarówno w teorii, jak i w polityce rynku pracy. W najprostszym ujęciu jest to łatwość przystosowywania się rynku pracy do zmieniających się warunków gospodarczych. Na elastycznym rynku pracy bez trudu można znaleźć zatrudnienie, ale również zwolnić pracowników (Jadamus-Hacura i Melich-Iwanek 2015, s. 37). Jak już wspomniano, istotne są zarówno zmiany dotyczące wysokości płac i wydajności pracy, jak i elastyczność wynagrodzeń (Kryńska 2001, Ostoj 2006).

W ujęciu makroekonomicznym elastyczność rynku pracy jest interpretowana jako mechanizm osiągania równowagi na rynku pracy podlegającym negatywnym efektom szoków gospodarczych. Im rynek jest bardziej elastyczny, tym szybciej powinno dojść do osiągnięcia równowagi (Kwiatkowski 2003, s. 20).

Elastyczność rynku pracy jest ujmowana w literaturze przedmiotu jako składająca się z kilku elementów: elastyczności zatrudnienia, czasu pracy, płac i podaży pracy (Jadamus-Hacura i Melich-Iwanek 2015, s. 38). Elastyczność zatrudnienia, bądź też elastyczność popytu na pracę, są to dostosowania ilościowe (numeryczne), a więc jest to możliwość dostosowania przez pracodawców poziomu zatrudnienia $\mathrm{w}$ przedsiębiorstwie (również podmiocie sektora publicznego) do bieżącej sytuacji wewnętrznej i zewnętrznej. W kontekście elastyczności popytu na pracę znaczenia nabierają również formy zatrudnienia dające pracodawcy większą swobodę, do których można zaliczyć: kontrakty dotyczące wykonania konkretnego zadania, zatrudnienie na niepełny etat lub na czas określony, pracę dorywczą, zdalną, na wezwanie, dzielenie się pracą i telepracę (Kwiatkowski 2003, s. 20; Skórska 2007, s. 141).

W ramach wprowadzania elastycznego czasu pracy odchodzi się od narzucania pełnowymiarowego czasu pracy - umożliwia się pracowanie w niepełnym wymiarze czasu, pozwala się na indywidualną organizację czasu pracy (ruchomy czas pracy) (Kwiatkowski 2003, s. 21; Skórska 2007, s. 137). Jak zauważa I. Ostoj (2006, s. 179-180), kwestie elastyczności zatrudnienia i elastyczności czasu pracy są z sobą ściśle związane. Stosowanie różnych form organizacji pracy powinno dawać możliwość niestandardowego rozliczania czasu pracy, np. w okresie kilku miesięcy. Pozwoliłoby to na zwiększenie zaangażowania pracowników, kiedy 
pracodawca tego potrzebuje, i jednocześnie na elastyczne rozliczanie godzin nadliczbowych w okresie, w którym to zapotrzebowanie jest mniejsze.

Istotą elastyczności płac jest możliwość dostosowania ich do zmieniających się warunków na rynku pracy, zmian rentowności przedsiębiorstwa, a także zmian efektywności, wydajności pracy pracownika. Ten element elastyczności rynku pracy w dużej mierze uzależniony jest od siły związków zawodowych, które z reguły dążą do utrzymania sztywności płac, oraz ingerencji państwa w rynek pracy w zakresie ustalania płacy minimalnej (Kwiatkowski 2003, s. 21).

W wypadku elastyczności podaży pracy ważną rolę odgrywa wrażliwość podaży na zmiany w zakresie jej determinant, takich jak płace czy struktura popytu na pracę, rozumiana również jako mobilność siły roboczej, zdolność do przystosowania się podaży pracy do zmian popytu na pracę. Jednym z przejawów wrażliwości podaży pracy na zmiany na rynku są dostosowania w zakresie aktywności zawodowej. W tym kontekście mobilność siły roboczej jest opisywana w literaturze przedmiotu jako mobilność zawodowa i kwalifikacyjna, międzyzakładowa oraz przestrzenna (Kwiatkowski 2003, s. 21).

Mobilność zawodowa i kwalifikacyjna dotyczy przede wszystkim gotowości do zmiany zawodu lub zdobycia nowych kwalifikacji, co wynika z warunków rozwijającej się gospodarki. Mobilność międzyzakładowa wiąże się z gotowością do zmiany miejsca zatrudnienia, co powinno być wynikiem działania mechanizmu rynkowego. $\mathrm{W}$ prezentowanym artykule najbardziej istotna będzie mobilność przestrzenna wewnętrzna i zewnętrzna, czyli gotowość do zmiany miejsca zamieszkania na taki region, w którym są lepsze perspektywy zatrudnienia, w kraju lub za granicą (Ostoj 2006, s. 180-182).

Elastyczność rynku pracy jest dość szerokim pojęciem. Składające się na nią elementy mogą się uzupełniać lub stanowić substytuty (Ostoj 2006, s. 182). Analizując zagadnienie elastyczności rynku pracy należy również pamiętać, że w zależności od przyjętej składowej i sytuacji gospodarczej dostosowania mogą przebiegać w dwóch kierunkach, np. prowadzić zarówno do zwiększenia, jak i zmniejszenia zatrudnienia bądź wynagrodzenia. W praktyce więcej problemów stwarza dążenie do redukcji zatrudnienia lub stawki płacy. Wiąże się to z koniecznością uwzględniania $w$ decyzjach pracodawcy obowiązujących przepisów dotyczących prawnej ochrony zatrudnienia (Hajn 2003, s. 51). Dużą rolę odgrywa w tym polityka państwa w zakresie realizacji koncepcji flexicurity, a więc zachowania równowagi pomiędzy wspieraniem elastycznego rynku pracy a ochroną zatrudnienia i zabezpieczeniem społecznym (Wiśniewski 2004, s. 294-295; Kucharski 2012, s. 38). 


\section{Teoria optymalnych obszarów walutowych}

W teorii optymalnych obszarów walutowych zakłada się, że krajowi opłaca się zrezygnować z posiadania własnej waluty tylko wtedy, gdy w wypadku zamiany waluty krajowej na wspólną korzyści wynikające z wyeliminowania kosztów transakcyjnych związanych $\mathrm{z}$ wymianą walut $\mathrm{w}$ handlu międzynarodowym będą większe niż koszty braku samodzielności w prowadzeniu polityki pieniężnej i kursowej (Kawalec 2014, s. 47).

Przez pojęcie obszaru walutowego należy rozumieć grupę regionów lub krajów, w których obowiązuje jedna waluta bądź różne w pełni wymienialne waluty o stałych kursach wymiennych. Określenie „optymalny” wiąże się z kolei z założeniem, że obszar walutowy musi spełnić określone wymogi (muszą zostać osiągnięte określone cele), formułuje się także warunki ich spełnienia. W literaturze przedmiotu nie opisano jednego w pełni spójnego, teoretycznego modelu optymalnego obszaru walutowego (Bukowski 2007, s. 25). R.J. McKinnon (1963, s. 717) stwierdził, że pojęcie optymalności jest złożone i trudno je określić w kategoriach wymiernych, wydaje się więc, że nie można było jej ująć w logicznie uporządkowany model.

Istnieje wiele uzupełniających się teorii, w których na podstawie częściowych rozwiązań modelowych podejmuje się próbę wyjaśnienia kwestii celów, warunków, a także mechanizmów dostosowawczych w ramach teorii optymalnych obszarów walutowych. Zagadnieniem tym oraz tematami dotyczącymi unii monetarnej zajmowali się w latach 50. XX w. J.E Meade (1957, s. 379-396) oraz T. Scitovsky (1958). Największy jednak wkład w sformułowanie oraz rozwój teorii optymalnych obszarów walutowych wniósł R.A. Mundell (1961, s. 657-665). Istotne uzupełnienia zaproponowali R.J. McKinnon (1963) oraz P.B. Kenen (1969). Zdaniem R.A. Mundella utworzenie optymalnego obszaru walutowego wymaga spełnienia warunku wysokiej elastyczności rynków pracy, a według R.J. McKinnona istotna jest również kwestia otwartości gospodarki. P.B. Kenen zwracał z kolei uwagę na zróżnicowanie struktury produkcji.

Kryteria opracowane przez R.A. Mundella dotyczą sprawności działania alternatywnych wobec kursu walutowego i niezależności banku centralnego mechanizmów dostosowawczych w wypadku wystąpienia asymetrycznych szoków makroekonomicznych, wynikających głównie z braku synchronizacji cykli koniunkturalnych. Jest to zatem podejście polegające na założeniu konieczności utworzenia unii walutowej i stosowania odpowiednich narzędzi niwelujących skutki ewentualnych szoków (podejście ex post). Z kolei R.J. McKinnon oraz P.B. Kenen w kwestii optymalnych obszarów walutowych skupili się na przeciwdziałaniu pojawieniu się asymetrii w cyklach koniunkturalnych oraz zmniejszeniu prawdopodobieństwa ich powstania (podejście ex ante) (Kawalec 2015, s. 182-183). 
Elastyczność rynków pracy jest substytutem elastyczności kursów walutowych w wypadku amortyzowania szoków w unii walutowej. Uzasadniając swoje stanowisko, R.A. Mundell (1961) analizował skutki szoków popytowych w dwóch modelowych gospodarkach. Założył, że oba państwa charakteryzuje pełne zatrudnienie, równowaga bilansu płatniczego oraz sztywność płac i doszło w nich do spadku cen w krótkim okresie. Rozpatrywał dwie sytuacje: państw, w których obowiązują różne waluty, oraz państw ze wspólną walutą. Z jego analiz wynika, że dostosowania rynkowe $\mathrm{w}$ wypadku państw $\mathrm{z}$ różnymi walutami powinny nastąpić poprzez zmianę kursu walutowego, w państwach zaś ze wspólną walutą zgodnie z modelem AS-AD - poprzez migrację siły roboczej (Sum 2011, s. 137).

Mobilnością siły roboczej określa się gotowość do migracji pracowników z kraju dotkniętego skutkami asymetrycznego szoku makroekonomicznego do krajów o lepszej sytuacji gospodarczej (mobilność przestrzenna). Wysoki poziom migracji siły roboczej usprawnia dostosowania cenowo-płacowe. Umożliwia krajom o mało elastycznych rynkach pracy (wolne dostosowanie płac lub sztywne płace zgodnie z założeniem R.A. Mundella) szybsze złagodzenie efektów szoków makroekonomicznych oraz przyspiesza powrót gospodarki do stanu równowagi (Borowiec 2011, s. 288-290). Z rozważań R.A. Mundella wynika, że region, w którym czynniki produkcji są mobilne, jest optymalnym obszarem walutowym, elastyczne kursy powinny być zatem wprowadzane w krajach o niskim poziomie mobilności czynników produkcji (Sum 2011, s. 137).

Uchylając założenie R.A. Mundella o sztywności płac, można również uwzględnić dostosowanie za pomocą zmian w poziomie płac (Sum 2011). Wysoki poziom elastyczności (giętkości) płac pozwala na obniżenie kosztów pracy w państwie, które zostało dotknięte asymetrycznym szokiem, co w relatywnie krótkim czasie umożliwia zwiększenie eksportu, produkcji oraz zatrudnienia. Konieczne jest przy tym sprawne funkcjonowanie rynku pracy oraz szybkie reagowanie przez przedsiębiorstwa na zmiany. Istotna jest tu zatem rola oraz wpływ związków zawodowych, które powinny ograniczać maksymalizowanie swojej użyteczności, wynikającej zarówno z wysokiego poziomu płac realnych, jak i wysokiego poziomu zatrudnienia ich członków. Przekłada się to więc na politykę władz centralnych w zakresie ustalania płac minimalnych i wspierania elastycznych form zatrudnienia lub tzw. umów śmieciowych, czyli umów niepodlegających prawu pracy (Borowiec 2011, s. 288).

Mimo że zarówno w teorii (modelu AS-AD), jak i w praktyce zakłada się możliwość dostosowań kanałem podażowym (dzięki mobilności siły roboczej) i popytowym (dzięki elastyczność płac), to jak wskazuje się w literaturze przedmiotu (Sum 2011, s. 137-138), dostosowanie za pomocą migracji siły roboczej jest dla gospodarki korzystniejsze, ponieważ ogranicza ryzyko szkodliwych zmian w cenach i dochodach w państwach jednolitego obszaru walutowego. 
R.J. McKinnon (1963), analizując zagadnienie otwartości gospodarki, odniósł się do skali korzyści wynikających z redukcji kosztów transakcyjnych w handlu międzynarodowym. Wysoki poziom zależności w handlu zagranicznym ma także prowadzić do synchronizacji cykli koniunkturalnych, które z kolei mają ograniczyć prawdopodobieństwo wystąpienia szoków asymetrycznych, a także wpłynąć na redukcję kosztów wynikających z prowadzenia wspólnej polityki pieniężnej.

Sformułowane przez R.J. McKinnona (1963) kryterium otwartości gospodarki definiowane jest jako stosunek dóbr wymienialnych do niewymienialnych w produkcji i konsumpcji w danym kraju (Sum 2011, s. 138). W literaturze przedmiotu można spotkać się z interpretacją tego kryterium jako relacji obrotów handlowych (dóbr wymienialnych, handlowych) do PKB (dóbr niewymienialnych, niehandlowych) (Kawalec 2015, s. 187, Kielec i Miłaszewicz 2016, s. 35). W rezultacie przeprowadzonych analiz autor ten stwierdził, że wraz ze wzrostem poziomu otwartości gospodarki maleje rola kursu walutowego w przywracaniu równowagi zewnętrznej, zwiększa się zaś jego negatywne oddziaływanie na stabilność cen. Zaproponowane przez R.J. McKinnona kryterium optymalności sprowadza się do stwierdzenia, że im wyższy jest poziom otwartości gospodarki, tym większe korzyści płyną z utworzenia wspólnego obszaru walutowego (Sum 2011, s. 138-141).

P.B. Kenen (1969) uzupełnił z kolei teorię optymalnych obszarów walutowych o kryterium dywersyfikacji struktury produkcji. Wysoki poziom zróżnicowania niweluje prawdopodobieństwo pojawienia się szoków asymetrycznych. Przy założeniu, że poszczególne państwa specjalizują się w produkcji określonych dóbr, ograniczenie popytu na nie wywołałoby reakcję tylko w jednym kraju. W sytuacji, gdy kraje charakteryzują się dywersyfikacją produkcji, także tej przeznaczonej na eksport, spadek zapotrzebowania na określone dobra dotknąłby wszystkie kraje, co ograniczyłoby ryzyko asymetrii i umożliwiło podjęcie jednolitych działań antykryzysowych.

Z rozważań P.B. Kenena można również wywnioskować, że unia walutowa powinna być tworzona przez kraje o zróżnicowanej strukturze produkcji, gdyż w gospodarce charakteryzującej się większą dywersyfikacją produkcji w mniejszym stopniu wykorzystuje się kurs walutowy jako narzędzie poprawy terms of trade niż w gospodarce o niższym poziomie dywersyfikacji (Sum 2011, s. 141).

Należy pamiętać, że przedstawiona teoria wielokrotnie została poddana krytyce i była uzupełniana. Zarzuty krytyków były związane przede wszystkim z brakiem jednoznacznej interpretacji proponowanych kryteriów oraz trudnością z ich kwantyfikacją. Jak zauważa K. Sum (2011, s. 135), w ramach tej dyskusji można wyodrębnić trzy główne nurty, do których należą:

- nowa teoria optymalnych obszarów walutowych, której prekursorem był J.C. Ingram (1969, s. 95-100); jego zdaniem istotnym kryterium optymalności powinna również być integracja rynków finansowych oraz integracja fiskalna; 
- teoria kosztów i korzyści - porównawcze ujęcie teorii optymalnych obszarów walutowych z lat 70. XX w. obejmujące analizę kosztów i korzyści z integracji walutowej, zaproponowane m.in. przez H.G. Grubela (1970); zagadnienie to było również rozwijane przez P.R. Krugmana (Krugman i Obstfeld 2000) i G. Tchorka (2014);

- koncepcja endogeniczności kryteriów optymalnych obszarów walutowych - koncepcja z lat 90. ubiegłego wieku, w której wskazywano na możliwość spełnienia kryteriów konwergencji ex post; do najważniejszych przedstawicieli tego nurtu teorii należą J.A. Frankel i A.K. Rose (1996), T. Bayoumi i B. Eichengreen (1997) czy G. Corsetti (2008).

Jak można zauważyć, teoria optymalnych obszarów walutowych nie jest jednolitą koncepcją i wciąż ewoluuje. Składa się na nią kilka modeli cząstkowych. Za główne kryteria optymalności przyjmuje się: mobilność czynników produkcji, elastyczność płac i cen, otwartość gospodarki i dywersyfikację produkcji. W rezultacie wielu polemik przyjmowane są ponadto dodatkowe kryteria optymalności.

Przeprowadzenie analizy opisanych koncepcji pozwala na sformułowanie różnych kryteriów optymalności, mogących stanowić uzupełnienie rozpatrywanego w artykule kryterium elastyczności rynku pracy, a także podstawę do dalszych badań.

\section{Analiza elastyczności rynku pracy w Polsce}

\subsection{Elastyczność podaży pracy}

Elastyczność podaży pracy w danym kraju rozumiana jest jako mobilność przestrzenna pracowników, czyli ich gotowość do przemieszczania się poza granice kraju. W prezentowanych analizach przyjęto, że miernikiem gotowości do migracji określającym mobilność siły roboczej w danym państwie będzie stosunek łącznej wielkości migracji (suma emigracji oraz imigracji) osób w wieku produkcyjnym (15-64 lat) do łącznej liczby ludności w tym wieku w danym kraju wyrażonej w procentach. Zasadniczo im wyższa jest wartość wskaźnika, tym większa jest skłonność do migracji i możliwość dostosowania gospodarki po szoku makroekonomicznym. Wyniki pomiaru przedstawiono na rys. 1.

Na podstawie przeprowadzonych analiz można stwierdzić, że państwa Unii Europejskiej cechują się bardzo dużym zróżnicowaniem poziomu mobilności siły roboczej. Ponad 55-krotnie wyższą mobilność odnotowano w wypadku Luksemburga $(7,23 \%)$ niż Słowacji $(0,13 \%)$. Polska charakteryzuje się umiarkowanym poziomem mobilności siły roboczej (1,39\%), który w ostatnich latach (2009-2015) utrzymuje się na zbliżonym poziomie (rys. 2). 


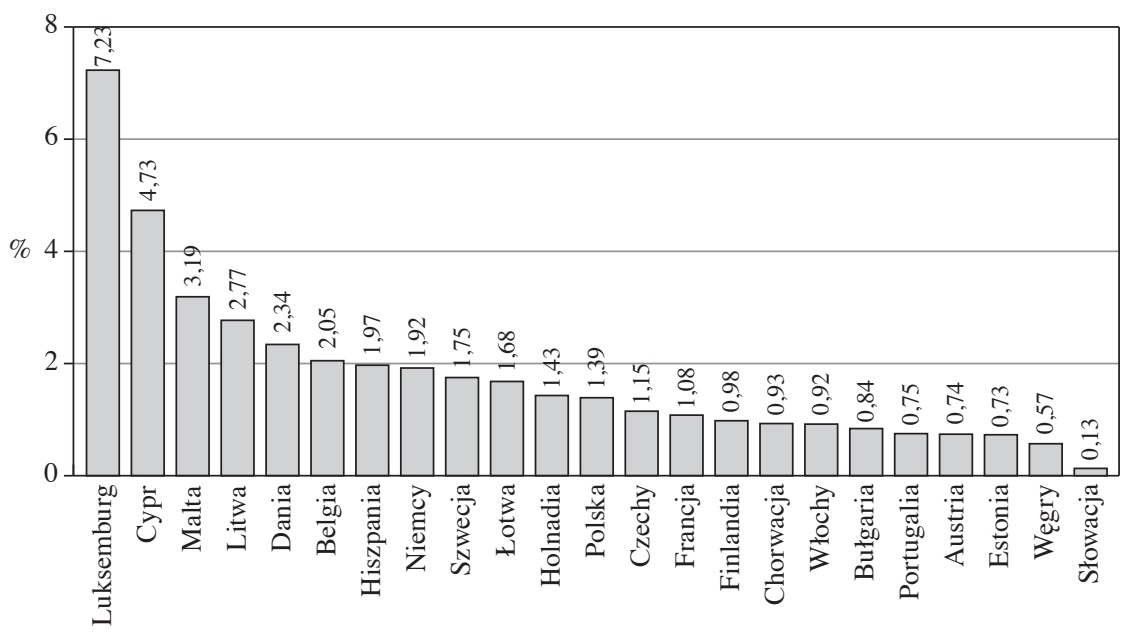

Rys. 1. Wskaźnik mobilności siły roboczej w państwach Unii Europejskiej - wartość średnia za lata 2000-2015 (w \%)

Uwaga: brak danych dla Irlandii, Grecji, Rumunii, Słowenii i Wielkiej Brytanii.

Źródło: opracowanie własne na podstawie danych Eurostatu.

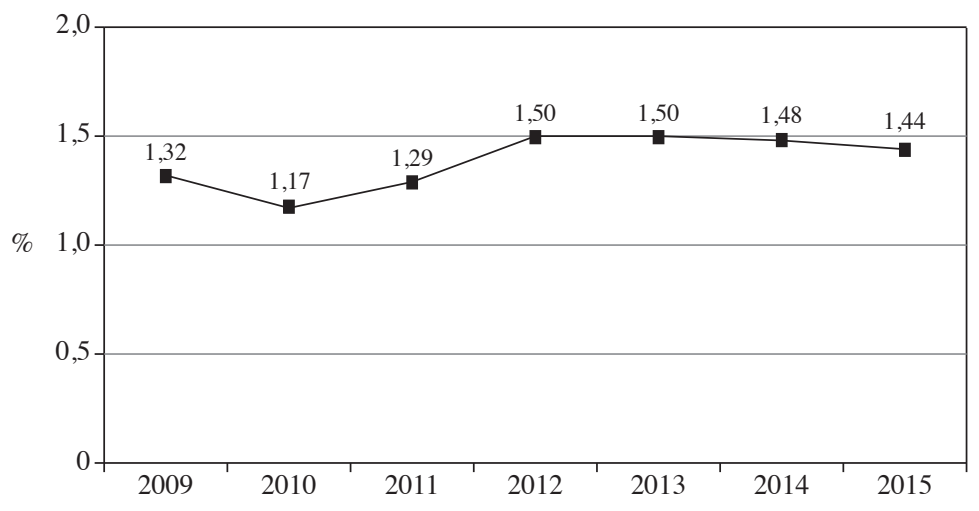

Rys. 2. Wskaźnik mobilności siły roboczej w Polsce w latach 2009-2015 (w \%) Źródło: opracowanie własne na podstawie danych Eurostatu.

Dokonując oceny wskaźnika mobilności siły roboczej w Polsce, nie można jednoznacznie stwierdzić, czy poziom mobilności siły roboczej będzie skuteczną 
alternatywą dla wykorzystania kursu walutowego jako mechanizmu stabilizującego gospodarkę po szoku makroekonomicznym. W tej sytuacji wskazane będzie poszukiwanie dodatkowych rozwiązań sprzyjających zwiększaniu elastyczności rynku pracy.

\subsection{Elastyczność zatrudnienia i czasu pracy}

Jak wspomniano, kwestie elastyczności zatrudnienia i elastyczności czasu pracy są z sobą ściśle związane. Zarówno możliwość tymczasowego zatrudniania pracowników, jak i pracowania w niepełnym wymiarze czasu pracy pozwalają na efektywniejsze dostosowanie wielkości bieżącego zatrudnienia do zmieniających się warunków na rynku pracy. Jako wskaźnik elastyczności tych elementów rynku pracy zaproponowano procentowy udział osób zatrudnionych na umowę na czas określony oraz procentowy udział osób zatrudnionych w niepełnym wymiarze czasu pracy w liczbie zatrudnionych ogółem. Wysoka wartość tych wskaźników powinna sprzyjać elastyczności rynku pracy.

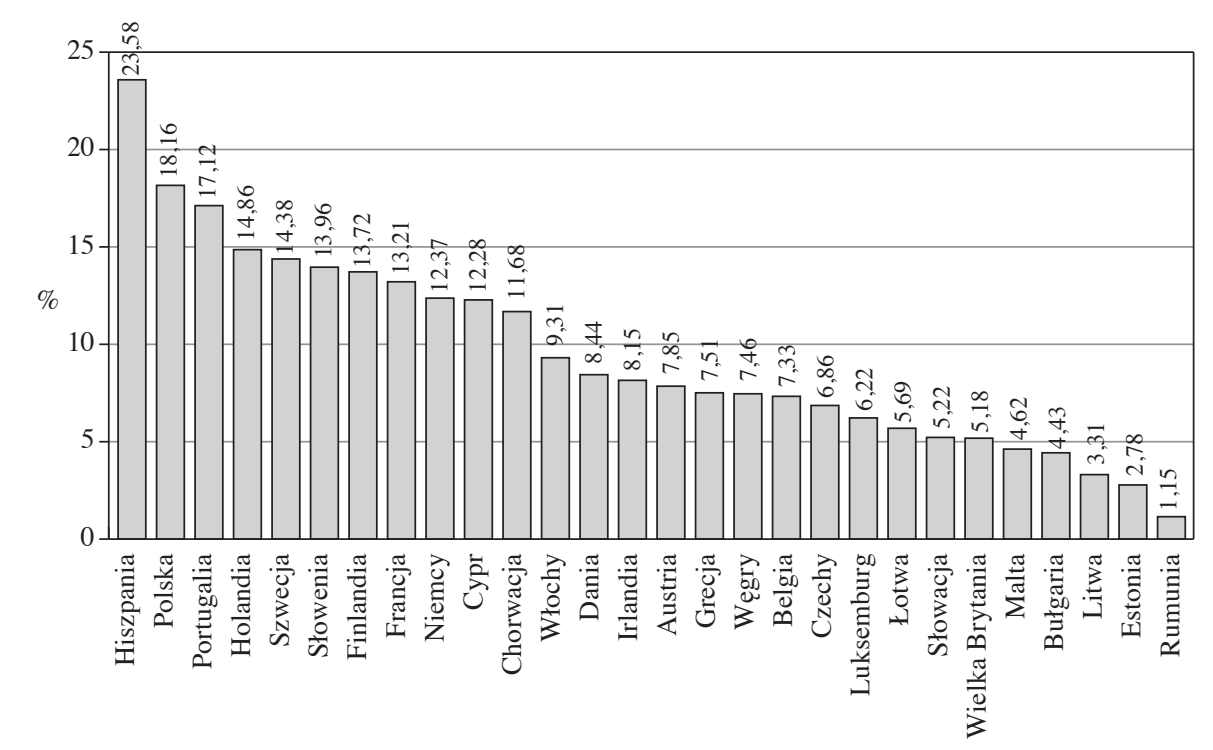

Rys. 3. Średni udział osób zatrudnionych na czas określony w liczbie zatrudnionych ogółem w państwach Unii Europejskiej - średnia z lat 2000-2016 (w \%)

Źródło: opracowanie własne na podstawie danych Eurostatu. 


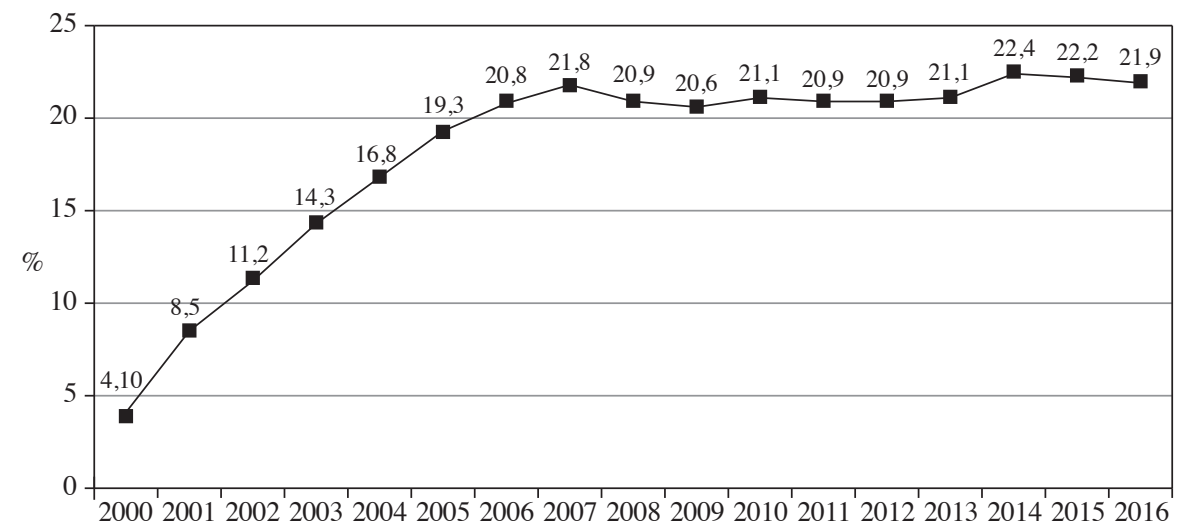

Rys. 4. Udział osób zatrudnionych na czas określony w liczbie zatrudnionych ogółem w Polsce w latach 2000-2016 (w \%)

Źródło: opracowanie własne na podstawie danych Eurostatu.

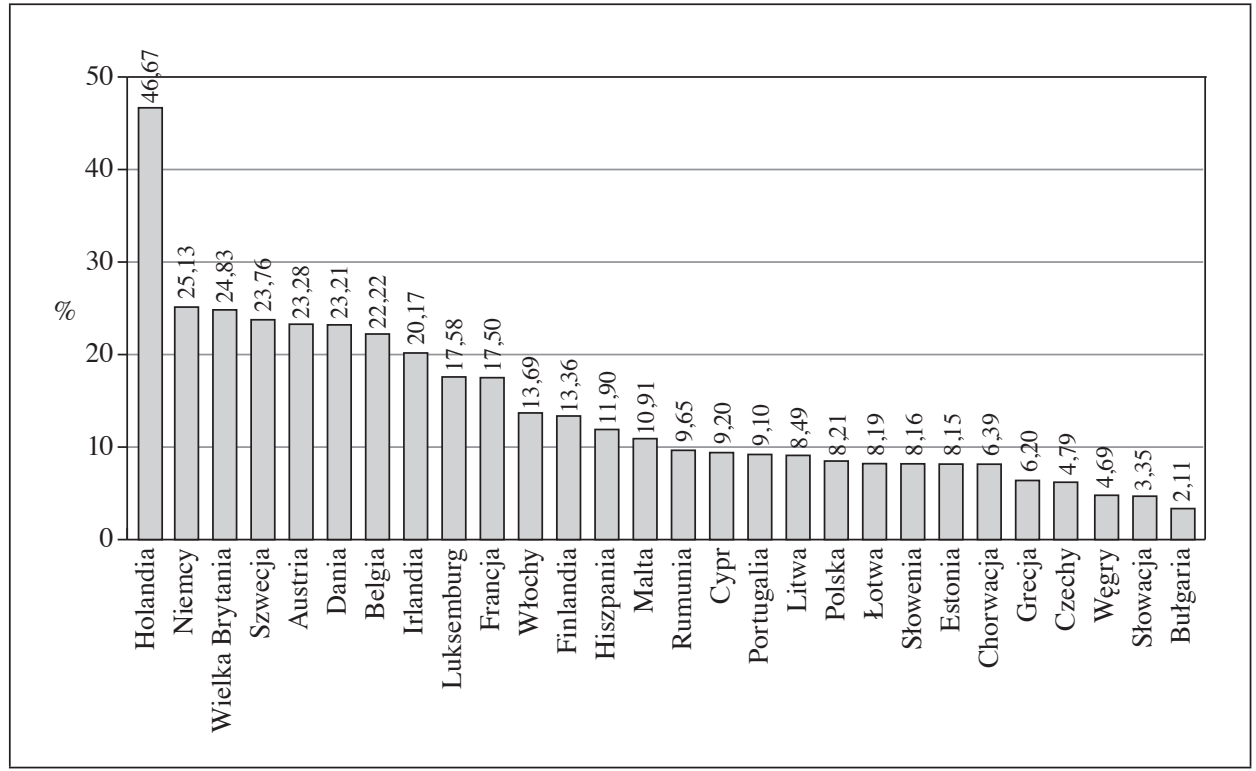

Rys. 5. Średni udział osób zatrudnionych w niepełnym wymiarze czasu pracy w państwach Unii Europejskiej - średnia z lat 2000-2016 (w \%) Źródło: opracowanie własne na podstawie danych Eurostatu. 
Biorąc pod uwagę elastyczność zatrudnienia, można zauważyć duże zróżnicowanie wartości wskaźnika w różnych krajach (rys. 3), o czym świadczy ponad 20-krotna różnica między Hiszpanią (23,58\%) a Rumunią (1,15\%). Pod względem wartości tego wskaźnika $(18,2 \%)$ Polska znalazła się na drugim miejscu, zaraz za Hiszpanią $(23,58 \%)$. Na podstawie danych przedstawionych na rys. 4 można zauważyć ponadto, że wskaźnik ten w wypadku Polski w badanym okresie wzrósł ponad 5-krotnie i od 2006 r. utrzymuje się na zbliżonym poziomie, przekraczającym $20 \%$. Jest to korzystny wynik.

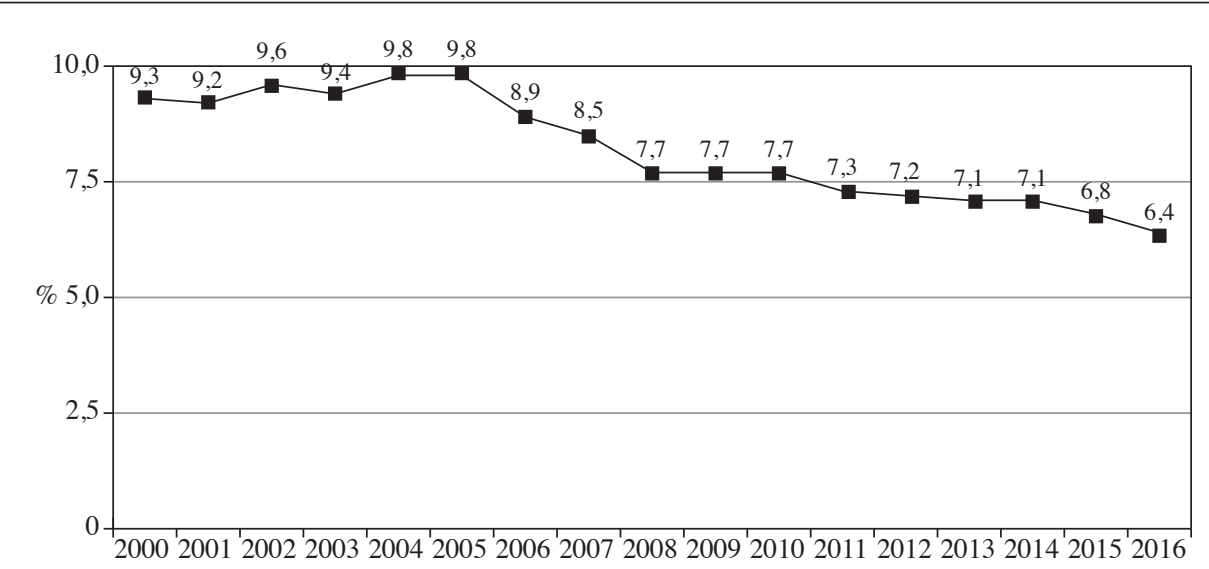

Rys. 6. Udział osób zatrudnionych w niepełnym wymiarze czasu pracy w liczbie zatrudnionych ogółem w Polsce w latach 2000-2016 (w \%)

Źródło: opracowanie własne na podstawie danych Eurostatu.

W wypadku elastyczności czasu pracy również zwraca uwagę duża rozpiętość wyników (rys. 5). Wskazuje na to ponad 22-krotna różnica między Holandią $(46,67 \%)$ a ostatnią w zestawieniu Bułgarią $(2,11 \%)$. W wypadku Polski wskaźnik ten jest na relatywnie niskim poziomie, wynik $8,21 \%$ sytuuje Polskę dopiero na 19 miejscu. Istotne jest również to, że wartość tego wskaźnika w Polsce w badanym okresie (rys. 6) zmniejszyła się z 9,3\% do 6,4\%. Można wnioskować, że w wypadku tego czynnika wartość wskaźnika była zbyt niska, aby mógł on istotnie wpłynąć na zwiększenie elastyczności rynku pracy. 


\section{Podsumowanie}

Przedmiotem prowadzonych analiz było zagadnienie elastyczności rynku pracy w Polsce w kontekście teorii optymalnych obszarów walutowych. Zgodnie z tą teorią oraz koncepcją R.A. Mundella (1961) elastyczność rynku pracy jest utożsamiana z mobilnością siły roboczej.

Zestawiając ogólne ujęcie zagadnienia elastyczności rynku pracy z teorią optymalności, można zauważyć, że kryterium zaproponowane przez R.A. Mundella nie pozwala na wyczerpujący opis zagadnienia elastyczności rynku pracy, ponieważ ogranicza się zasadniczo do kwestii elastyczności podaży pracy (mobilności siły roboczej) oraz elastyczności płac, w swojej teorii R.A. Mundell zakłada sztywność płac.

Przeprowadzone analizy pozwoliły na ocenienie, czy warunek optymalności jest spełniony, a więc czy zgodnie z teorią R.A. Mundella istnieje alternatywny wobec wykorzystania kursu walutowego mechanizm stabilizacji gospodarki po szoku makroekonomicznym. W tym ujęciu takim mechanizmem jest dostosowanie dzięki mobilności siły roboczej, w szerszym zaś ujęciu pozostałe elementy rynku pracy, nieuwzględnione przez R.A. Mundella, powinny wspierać elastyczność rynku pracy.

W wyniku przeprowadzonych analiz nie udało się uzyskać jednoznacznego rozstrzygnięcia przedstawionego problemu. Do najważniejszych wniosków należy zaliczyć stwierdzenie występowania dużych rozbieżności wartości wskaźników charakteryzujących badane elementy rynku pracy w państwach Unii Europejskiej oraz umiarkowanego, lecz niedostatecznego poziomu elastyczności rynku pracy w Polsce.

Poziom elastyczności rynku pracy w Polsce wskazuje zatem na to, że nie ma skutecznego rozwiązania stanowiącego alternatywę dla wykorzystania elastyczności kursu walutowego w dostosowaniach makroekonomicznych. Biorąc pod uwagę to, że elastyczność rynku pracy jest warunkiem optymalności obszaru walutowego, należy wstrzymać się przed podjęciem decyzji o usztywnieniu kursu walutowego i przystąpieniu przez Polskę do strefy euro.

\section{Literatura}

Bayoumi T., Eichengreen B. (1997), Ever Closer to Heaven? An Optimum Currency Area Index for European Countries, ,European Economic Review”, vol. 41, nr 3-5, https:// doi.org/10.1016/S0014-2921(97)00035-4.

Borowiec J. (2011), Ekonomia integracji europejskiej, Wydawnictwo Uniwersytetu Ekonomicznego we Wrocławiu, Wrocław.

Bukowski S.I. (2007), Unia monetarna. Teoria i polityka, Difin, Warszawa. 
Corsetti G. (2008), A Modern Reconsideration of the Theory of Optimal Currency Areas, European Economy - Economic Papers No 308, Brussels, https://doi.org/10.2765/41116.

Ertman A. (2011), Zróżnicowanie elastyczności rynków pracy w wybranych krajach europejskich oraz USA w świetle metody TOPSIS, „Oeconomia Copernicana”, vol. 2, nr 3.

Frankel J.A., Rose A.K. (1996), Endogeneity of the Optimum Currency Area Criteria, NBER Working Paper Series, No 5700, Cambridge, MA, https://doi.org/10.3386/ w5700.

Grubel H.G. (1970), The Theory of Optimum Currency Areas, „The Canadian Journal of Economics", vol. 3, nr 2, https://doi.org/10.2307/133681.

Hajn Z. (2003), Elastyczność popytu na pracę w Polsce. Aspekty prawne (w:) Elastyczne formy zatrudnienia i organizacji pracy a popyt na pracę w Polsce, red. E. Kryńska, IPiSS, Warszawa.

Ingram J.C. (1969), Comment: The Currency Area Problem (w:) Monetary Problems of the International Economy, red. R.A. Mundell, A.K. Swoboda, The University of Chicago Press, Chicago-London.

Jadamus-Hacura M., Melich-Iwanek K. (2015), Elastyczność współczesnych rynków pracy, „Studia Ekonomiczne. Zeszyty Naukowe Uniwersytetu Ekonomicznego w Katowicach", nr 220.

Kawalec M. (2014), Założenia teoretyczne a funkcjonowanie unii walutowej (w:) Kryzys Unii czy kryzys w Unii? Kierunki dyskusji nad przyszłościq integracji europejskiej, red. H. Tendera-Właszczuk, Difin, Warszawa.

Kawalec M. (2015), Optymalny obszar walutowy strefy euro - proces czy stan (w:) Nowe państwa członkowskie w Unii Europejskiej. Diagnoza i perspektywy, red. H. Tendera-Właszczuk, Difin, Warszawa.

Kenen P.B. (1969), The Theory of Optimum Currency Areas: An Eclectic View (w:) Monetary Problems of the International Economy, red. R.A. Mundell, A.K. Swoboda, The University of Chicago Press, Chicago-London.

Kielec K., Miłaszewicz D. (2016), Powstanie europejskiej unii walutowej jako optymalnego obszaru walutowego, ,Studia i Prace WNEiZUS”, nr 44, https://doi.org/10.18276/ sip.2016.44/1-03.

Kryńska E. (2001), Elastyczność zatrudnienia w Polsce $i$ w Unii Europejskiej, „Gospodarka Narodowa", nr 1-2.

Krugman P.R., Obstfeld M. (2000), International Economics: Theory and Policy, Addison Wesley, Boston, MA.

Kucharski M. (2012), Koncepcja flexicurity a elastyczne formy zatrudnienia na polskim rynku pracy, Dom Wydawniczy Elipsa, Warszawa.

Kwiatkowski E. (2003), Elastyczność popytu na prace w teoriach rynku pracy (w:) Elastyczne formy zatrudnienia i organizacji pracy a popyt na prace w Polsce, red. E. Kryńska, IPiSS, Warszawa.

McKinnon R.I. (1963), Optimum Currency Area, „The American Economic Review”, vol. 53, $\mathrm{nr} 4$.

Meade J.E. (1957), The Balance-of-payments Problems of a European Free Trade Area, „The Economic Journal”, vol. 67, nr 267, https://doi.org/10.2307/2227357.

Mundell R.A. (1961), A Theory of Optimum Currency Areas, „The American Economic Review", vol. 51, nr 4.

Ostoj I. (2006), Elastyczność rynku pracy a ograniczanie bezrobocia, „Studia Ekonomiczne. Zeszyty Naukowe Uniwersytetu Ekonomicznego w Katowicach”, nr 38. 
Scitovsky T. (1958), Economic Theory and Western European Integration, Allen and Unwin, London.

Skórska A. (2007), Przeciwdziałanie bezrobociu (w:) Ekonomia rynku pracy, red. D. Kotlorz, Wydawnictwo Akademii Ekonomicznej w Katowicach, Katowice.

Sum K. (2011), Teoria optymalnych obszarów walutowych, „International Journal of Management and Economics", nr 29.

Tchorek G. (2014), Teoretyczne podstawy integracji walutowej (w:) Mechanizmy funkcjonowania strefy euro, red. P. Kowalewski, G. Tchorek, J. Górski, NBP, Warszawa.

Trzeciakowski R. (2017), Indeks Elastyczności Zatrudnienia 2018: polski kodeks pracy w ogonie krajów UE i OECD. Dlaczego polscy pracownicy maja gorzej?, Forum Obywatelskiego Rozwoju, Warszawa.

Wiśniewski Z. (2004), Rynki pracy w przyszłości - deregulacja a zatrudnienie (w): Przyszłość pracy wXXI wieku, red. S. Borkowska, IPiSS, Warszawa.

\section{The Flexibility of Poland's Labour Market in the Light of the Theory of Optimum Currency Areas}

(Abstract)

Labour market flexibility is understood as the ability of the market to smoothly adapt to changing economic conditions. To function smoothly and be flexible, the labour market must be able to quickly respond to the demand for labour and changes taking place in the economy. In the context of the theory of optimum currency areas, labour market flexibility plays a greater role as a substitute for flexibility of exchange rates in reducing shocks to the monetary union. The aim of this work is to analyse the current level of labour market flexibility in Poland, in particular in the context of the optimum currency area theory criteria. The most important conclusion from the analysis is that Poland's labour market is too inflexible, and is therefore an effective alternative to exchange rate flexibility in macroeconomic adjustments.

Keywords: labour market flexibility, the theory of optimal currency areas, the euro zone, the monetary union. 